\title{
STRUCTURE DESIGN AND STRENGTH ANALYSIS OF CHILD SEAT FOR MOTORCYCLE
}

\author{
D. Ginanti, H. N. Fauzah, M.B.N. Akbar, F. Triawan \\ Department of Mechanical Engineering, Faculty of Engineering and Technology, Sampoerna \\ University \\ Jl. Raya Pasar Minggu Kav.16, Pancoran, Kota Jakarta Selatan 12780 \\ dara.ginanti@sampoernauniversity.ac.id
}

\begin{abstract}
Abstrak
Banyak orang di Indonesia mengalami masalah keselamatan yang serius dalam membawa anak-anak mereka mengendarai sepeda motor. Kursi anak yang layak diperlukan untuk menjamin keselamatan anak dan pengendara itu sendiri. Dalam tulisan ini, desain struktur kursi anak sepeda motor yang menggunakan sistem spring-damper disajikan sebagai acuan untuk membangun tempat duduk yang aman dan nyaman. Analisis kondisi statik, kondisi dinamika, tekuk, dan juga kelelahan juga dilakukan dihitung dan menghasilkan beberapa faktor keamanan. Faktor keamanan ditemukan dalam kisaran 1-11. Berbasis Dari hasil analisis tersebut dapat ditarik kesimpulan bahwa kursi anak tersebut aman. Karena beberapa perhatian terkait dengan keselamatan, inovasi ini direkomendasikan untuk diterapkan untuk produksi massal, selanjutnya perbaikan dan optimalisasi juga dimungkinkan untuk desain ini.
\end{abstract}

Kata kunci: Child seat, motorcycle usage, structure design, strength analysis, static dan fatigue loads.

\begin{abstract}
Many people in Indonesia are having a serious safety issue in bringing their children to ride a motorcycle. A proper child seat is needed to guarantee the safety of the child and the rider itself. In this paper, the structural design of a child seat for a motorcycle using a spring-damper system is presented as a reference to build a safe and comfortable seat. Analysis of the static condition, dynamics condition, buckling, and also fatigue is also done calculated and it is resulting in some safety factors. The safety factors are found to be in the range of 1-11. Based on that analysis result, the conclusion that can be highlighted is that the child seat is safe. Due to some concern related to safety, this innovation is recommended to be applied for mass production, furthermore, improvement, and optimization is also possible for this design.
\end{abstract}

Keywords: Child seat, motorcycle usage, structure design, strength analysis, static dan fatigue loads.

\section{PENDAHULUAN}

Nowadays, a lot of Indonesian citizens are using a motorcycle in their daily life. In 2018, the number of motorcycles itself in Jakarta is up until 14,745 units. [1] Those number is still increasing until now due to the flexibility of the motorcycle itself to ride in various kinds of roads, its affordable cost, and also its functionality. Along with this increasing number, the rate of transportation accidents on the road is also increasing. An accident does not only happen to adults, but also to children who are brought to ride. A data found by Phyllis Agran et al in their journal shows that seventy percent of children in a range of 4 to 9 years old sustained a head or face injury due to they are brought to ride in a motorcycle with less safety. [5] Upper-torso and extremity injuries were infrequent, despite, lower torso injuries are more frequent to happen and it occurred primarily in frontal impacts in both the back and front seats. [5] Frontal impacts resulted in a greater proportion of serious injuries than rear impacts. [5] Due to this high possibility of an accident, many people are worried to bring their child to ride.

In this paper, a safety child seat is designed to solve this worry. Analysis of the safety of this design is done by calculating the safety factor on the static condition and dynamics conditions. To see how strong and durable this design is, a buckling and fatigue analysis is also done.

The child seat is designed to be placed in the front of the motorcycle, it also equipped with a clamping system using bolts and a seat belt to give an

\section{Ginanti, D, dkk.; Structure Design And Strength Analysis Of Child Seat For Motorcycle}


extra protection for the child. This clamping and seat belt system is applied to the seat to keep the child stay in its position when some unwanted impact occurs.

\section{METODE PENELITIAN}

The methodology that is used during this work to design a child seat is a literature review to some e-journals, papers, and online shopping sites. Market research is also done to make some specifications that meet the needs of the consumer. Those specification researches are becoming the first step in making this child seat. Consideration is also made to make the rider comfortable to use this child seat. A specific dimension is designed for the child seat so that it will not disturb the rider to ride the motorcycle. A too high seat may cover the rider view and a too-wide seat may make the driver difficult to ride the motorcycle. If the rider is disturbed, it will increase the possibility of an accident to happen. Hence why this consideration is very important because it will not only affect the comfort of the user but also affecting safety.

There are three categories of specification, those categories are primary, secondary, and tertiary. The primary specification is the main specification that is being prioritized on designing the seat. Then, the secondary and the tertiary specification is made to complete the function and the features of the seat. These three specification categories are becoming the goals of the designed seat. At the end of the designing process, the seat should meet all the specification that is listed. Below is the list of the specification that is set to design this child seat.

\section{Primary:}

- Having a feature of shock resistance, for both vibration (when the motorcycle roads in a rough way) and impact (when an accident happens, and some unwanted movement is occurring).

- Safe for the child. This is the primary specification of the product. The product must be safe for the user. It should be placed in a safe position somewhere in the motorcycle. It also should strength enough to hold the weight of the baby.

\section{Secondary:}

- Comfortable for the rider. The product must be in the right dimension to avoid uncomfortable of the rider. A too big size or too high dimension may affect the comfort of the rider to ride the motorcycle.
- Soft, the material for the pillow seat must be soft enough to make the child feel comfortable during the usage.

- Strong but light. This specification is the second most needed specification based on the research to the marketplace. Most people are love to but a product that is strong but it does not make the weight become a problem.

- Not consuming a lot of space. Usually, the more features a product can offer, the bigger the size the product will be. However, for this designed seat, it is set for having many features, but still in the proper size to not consuming a lot of sizes.

\section{Tertiary:}

Unique design. This specification can be fulfilled if the first and second specification is fulfilled. The unique design that is proposed should not disturb the other specification.

After evaluating the specification, the next step is to brainstorm the design of the chair itself. This brainstorming process includes some hand sketching and the output of this process is a proposed design that later on will be designed using software to make the $3 \mathrm{D}$ design. All the 3D design shown in this paper is made using the Solid work application.

The next processes are to determine the specific working system and the material of the product. In this step, an iterative review is done again to make sure that the design meets the specification that has been set. This process includes dimensioning for some detailed components.

Ultimately, the analysis process is done to evaluate whether the designed child seat is safe for the user or not. Four kinds of analysis are done, those analyses are the static analysis, dynamics analysis, buckling analysis, and fatigue analysis.

\section{HASIL DAN PEMBAHASAN}

Considering the safety, market needs, and engineering theories of component design are very important to apply for designing this product. By considering those fields, the product may work effectively and securely. From the three possible place options to place the child seat (front-side, backside, and adaptable places), the chosen one is lending on the front-side design. This designed seat is also equipped with a seat belt, this seat belt works as extra protection for the child and will keep the child safe to sit while the motorcycle is on riding. Furthermore, for the seat itself, it will be clamped to the motorcycle with some bolts. This clamping 
mechanism will make the seat stay on its position although some vibration applied to it while the motorcycle is on riding. With this system, seat falls are avoided. Here, figure 1 is showing the 3D design of the child seat.

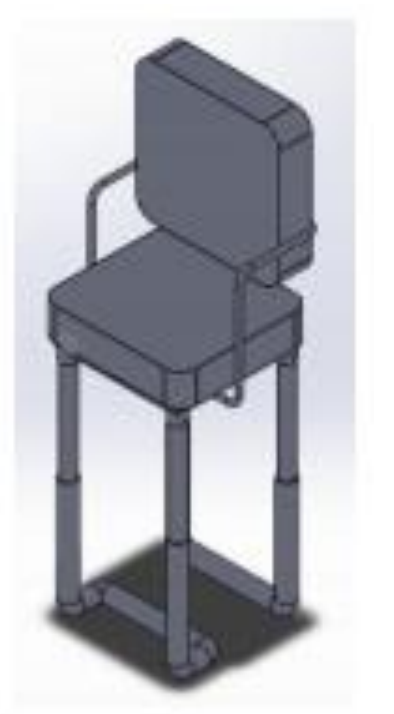

\section{Gambar $13 D$ design of the chair}

The biggest improvement that is made in this designed seat is lending on its features of shock resistance. This feature is supported by a spring damper system that is just similar to a spring system on a bicycle. [10] By applying this damping system, it can minimize the failure of the structure and the effect of vibration due to the rough road. [6] This also makes the seat more comfortable. Hence, the child who seats in the child seat will feel less vibration. A damping system is the most suitable, simple, and effective method to reduce vibration and increase the safety of the child. [7]

The other improvement also exists on its base. The two front legs and the two back legs are connected. This connection will minimize the different rates of vibration on each of the leg thus the seat will be more stable and can stand steadily during the using time.

The designed chair is composed of seven main parts. Figure 2 below will show the detailed component on the chair.

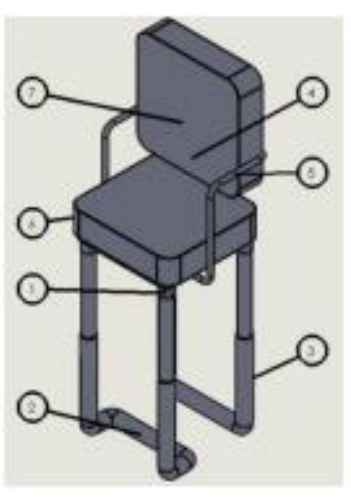

Gambar 2 3D design and its detailed parts

Tabel 1 Name of the Components

\begin{tabular}{cc}
\hline No & Part \\
\hline 1 & Frame \\
\hline 2 & Front leg \\
\hline 3 & Behind Leg \\
\hline 4 & Connector \\
\hline 5 & Handle \\
\hline 6 & Seat Pillow \\
\hline 7 &
\end{tabular}

After defining the components, another research is done in purpose to choose the most suitable material for the seat. In this stage, dimensioning is also be done for the whole component. These two stages are very important to define the strength of the seat product. All the data that are decided here will be used on the analysis stage. Hence why the detailed data for each of the material should be obtained. If at the end of the analysis process the safety factors are not big and safe enough for the seat, the changing on the material and the dimension is much recommended for the optimization and safety factors improvements.

The next process is the analysis process. The first analysis that must be done is static. Static analysis will give the data on how to strengthen the product will be when it is used in a static condition. This is the most fundamental analysis, if the structure fails to pass the static analysis, it cannot go to the next analysis and the design must have some modification. In this designed child seat, the critical part of the structure is lending on the frame. Thus, the part that will be analyzed is the frame. The frame is the component that connects the pillow seat and the legs. This component is critical because it will become the first part that fails in a condition of overload forces. 
Tabel 2 Detailed Component of the Chair

\begin{tabular}{|c|c|c|}
\hline No & Material & Dimension \\
\hline $6 \& 7$ & Polyester & $5 \mathrm{~cm}$ in height \\
\hline 1 & $\begin{array}{c}\text { Hollow Pipe } \\
\text { Stainless Steel } \\
\text { [1] }\end{array}$ & $\begin{array}{c}\text { Thickness }=1.4 \\
\text { mm ; Diameter }= \\
2.54 \mathrm{~cm}\end{array}$ \\
\hline $2 \& 3$ & $\begin{array}{c}\text { Spring } \\
\text { Damper [2] }\end{array}$ & $10 \mathrm{~mm}$ \\
\hline 4 & $\begin{array}{c}\text { Stainless Steel } \\
\text { [3] }\end{array}$ & $\begin{array}{l}\text { Thickness }=1 \mathrm{~cm} \\
\text { Length }=20 \mathrm{~cm}\end{array}$ \\
\hline 5 & $\begin{array}{l}\text { Hollow Pipe } \\
\text { Stainless Steel }\end{array}$ & $\begin{array}{l}\text { Diameter }=5 \mathrm{~mm} \\
\text { Thickness }=1 \mathrm{~mm}\end{array}$ \\
\hline $\begin{array}{l}\text { Seat } \\
\text { Belt }\end{array}$ & $\begin{array}{c}\text { Woven Nylon } \\
{[4]}\end{array}$ & $4.8 \mathrm{~mm}$ in width \\
\hline
\end{tabular}

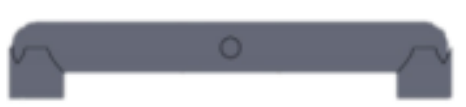

Gambar 3 The frame component below the seat

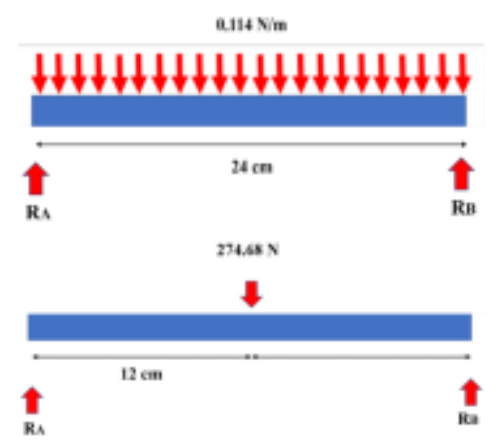

\section{Gambar 4 The Free Body Diagram of the Frame}

To do the analysis, some assumptions should be set. Then, a free body diagram should be presented as a guide to doing the analysis correctly. The assumption must be clearly defined to avoid a wrong analysis. A consideration on which part should be neglected is also needed, in this analysis, the engineering sense is needed.

The reaction force of the frame can be obtained from a calculation of moment at point A using the equation (1). The output of this calculation is the force at point B or RB. Furthermore, to get the other reaction, equation (2) is applied. From this calculation, the result is RA. In this case, RA and RB are having the same value, the value is $137.34 \mathrm{~N}$. Assumption:

- The thickness of the foam is neglected

- The calculation of each joint is neglected

- The legs of the chair have the same radius
- 2D analysis

- Handle analysis is neglected

- Static analysis in the frame Max child weight $=25 \mathrm{~kg}$

Max chair weight $=3 \mathrm{~kg}$

Total max weight $=28 \mathrm{~kg}=274.68 \mathrm{~N}$

Sy $=120 \mathrm{MPa}$

$\sigma \mathrm{y}=240 \mathrm{MPa}$

$\sum \mathrm{Ma}=0$

$-274.68(0.12)+R b(0.24)=0$

$R b(0.24)=32.96$

$R b=137.34 \mathrm{~N}$

$\sum \mathrm{Fy}=0$

$R a-274.68+137.34=0$

$\mathrm{R} a=137.34 \mathrm{~N}$

The cross-section of the legs is shown in figure 5 below.

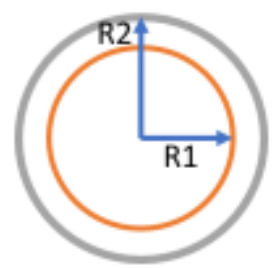

\section{Gambar 5 The cross-section area of the legs}

The smaller diameter can be found using equation (3), then, the inertia can be found using equation (4).

$$
R 1=R 2-t
$$

$R 1=1.27-0.14$

$R 1=1.13 \mathrm{~cm}$

$R 2=1.27 \mathrm{~cm}$

$$
\begin{aligned}
& I x=\frac{1}{4} \pi\left({R_{2}}^{4}-R_{1}{ }^{4}\right) \ldots \ldots \\
& I x=\frac{1}{4} \pi\left(1.27^{4}-1.13^{4}\right) \\
& I x=0.763 \times 10-8 m 4
\end{aligned}
$$

Therefore, after getting the value of inertia, to find the principal stresses of the structure, it is compulsory to find the normal stress and the shear stress that is applied to the frame. By using equation (5) and (6), the normal stress is known to be 54.86 $\mathrm{MPa}$, while the shear stress is $5.08 \mathrm{MPa}$. Those values will be used to calculate the principal stress of the frame, the equation that is used to find the principal stresses is equation (7). The result from this calculation shows that the value of the principal stresses is $55.326 \mathrm{MPa}$ and $-0.466 \mathrm{MPa}$.

\section{Ginanti, D, dkk.; Structure Design And Strength Analysis Of Child Seat For Motorcycle}


$\sigma=\frac{M c}{I}$

$\sigma=\frac{31.96 \times 1.27 \times 10^{-2}}{0.763 \times 10^{-8}}=54.86 \mathrm{MPa}$

$\tau=\frac{V Q}{I t}$

$\tau=\frac{137.34 \times 0.404 \times 10^{-6}}{0.763 \times 10^{-8} \times 1.4 \times 10^{-3}}=5.08 \mathrm{MPa}$

$\sigma_{1,2}=\frac{\sigma}{2} \pm \sqrt{\frac{\sigma^{2}}{2}+\tau^{2}}$

$\sigma_{1,2}=\frac{54.86}{2} \pm \sqrt{\frac{54.86^{2}}{2}+5.08^{2}}$

$\sigma_{1,2}=27.43 \pm 27,849 M P a$

After getting the value of the principal stresses, it needs to be categorized whether includes in case 1 , case 2 , or case 3 . Case 1 is a case when the two principal stresses have positive values. Despite, case 2 is a case when one of the principal stresses is positive and the other one is negative. For case 3 , it is applied when both the value of the principal stresses are negative. From the previous calculation, it is known that the child seat structure is categorized as case 2 , thus, the safety factor can be calculated by using equation (8). From this calculation, the safety factor of the static analysis is found to be 2.15 .

$$
\begin{aligned}
& n=\frac{S y}{\sigma 1-\sigma 2} \ldots \ldots \ldots \ldots \\
& n=\frac{120 \mathrm{MPa}}{55.792 \mathrm{MPa}}=2.15
\end{aligned}
$$

The next analysis is buckling analysis. The leg structure of the child seat is quite long $(0.21 \mathrm{~m})$ and the beam may buckle. Thus, a buckling analysis is needed to make sure that the structure of the seat will not buckle when it is being used to hold the child. The assumption that is set to do this analysis is that each of the leg's structure receives a load which has a value of $\mathrm{P}=68.67 \mathrm{~N}$. This $\mathrm{P}$ is coming from the total force that is received by the frame, then it is distributed to the four legs. This value is substituted to the formula to find the $\mathrm{P}$ critical and the $\mathrm{P}$ allowable. Moreover, the normal stress is found by using equation (9), the value is found to be 30.807 $\mathrm{MPa}$. Next is to find the critical normal stress, it is done using equation (10), the value is found to be 356.16 MPa. In this analysis, the safety factor is found by using the equation (11) and the value is 11.56.

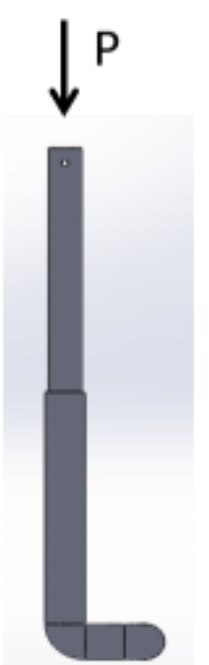

Gambar 6 The leg component that is analyzed

$$
\begin{aligned}
& \sigma=\frac{P_{a l l}}{A}=\frac{P_{c r}}{A x S}=\frac{\pi E I}{A x S x L e^{2}} . \\
& \sigma=\frac{\pi \times 180 \times 10^{9} \times 0.763 \times 10^{8}}{0.056 \times 10^{-4} \times 23.62 \times 0.42^{2}}=30.897 \mathrm{MPa} \\
& \sigma_{c r}=0.877 \frac{E \pi^{2}}{\left(\frac{L}{r}\right)^{2}} \\
& \sigma_{c r}=0.877 x 406.11 \mathrm{MPa}=356.16 \mathrm{MPa} \\
& n=\frac{\sigma_{c r}}{\sigma} \text {. } \\
& n=\frac{356.16}{30.807}=11.56
\end{aligned}
$$

After done the static and buckling analysis, the finding shows that the structure is safe enough to hold a child. Then, the analysis is continued to the next condition which is dynamic. An analysis in a dynamics condition is called as a dynamics analysis. In other words, a dynamics analysis is an analysis of how strong the seat will be if it is used in a driven motorcycle.

This analysis works on the frame structure. In this analysis, a couple of moments are added on both sides of the frame in the same direction. The assumption that was taken in this analysis is that the child seat is on use to hold a child with a maximum weight of $25 \mathrm{~kg}$ and the motorcycle is ridden with a velocity of $60 \mathrm{~km} /$ hour along 100 meters distance. The value of the additional moment can be found by finding the value of the kinetic energy first, then this value is substituted to the equation of work in (13) to find F. Ultimately, the value of $F$ is multiplied with the distance to find the moment.

The further step is to find the principal stresses by using equation (5), (6), and (7). Then, the last step for the analysis of the whole dynamics is 
done by finding the safety factor using equation (8). The value is found to be 1.687 .

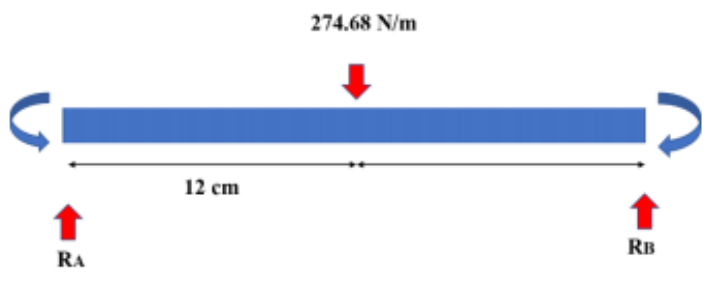

Gambar 7 The frame in dynamics analysis

$$
\begin{aligned}
& n=\frac{1}{2} m v^{2} \\
& n=\frac{1}{2} x 28 \times 16.67^{2}=3890.44 J \\
& W=F x d \\
& F=\frac{W}{d}=\frac{3890.44}{100}=38.90 \mathrm{~N} \\
& M c=F x s=38.90 \times 0.24=9.34 \mathrm{Nm} \\
& \sigma=\frac{M c}{I}=\frac{42.296 \times 1.27 \times 10^{-2}}{0.763 \times 10^{-8}}=70.40 \mathrm{MPa} \\
& \tau=\frac{V Q}{I t} \\
& \tau=\frac{137.34 \times 0.404 \times 10^{-6}}{0.763 \times 10^{-8} \times 1.4 \times 10^{-3}}=5.08 \mathrm{MPa} \\
& \sigma_{1,2}=\frac{\sigma}{2} \pm \sqrt{\frac{\sigma^{2}}{2}+\tau^{2}} \\
& \sigma_{1,2}=\frac{70.40}{2} \pm \sqrt{\frac{70.40^{2}}{2}+5.08^{2}} \\
& \sigma_{1,2}=35.20 \pm 35.56 \mathrm{MPa} \\
& \sigma_{1}=70.765 \mathrm{MPa} \\
& \sigma_{2}=-0.36 \mathrm{MPa} \\
& n=\frac{S y}{\sigma 1-\sigma 2} \\
& n=\frac{\frac{\sigma 1-\sigma 2}{120 \mathrm{MPa}}}{71.125 \mathrm{MPa}}=1.687
\end{aligned}
$$

After having all the analyses on the structure, the next analysis that should be done is the fatigue analysis to determining the fatigue failure on the child seat. The fatigue analysis of the leg and the frame is the same. It is because they have the same material also the same size for the diameter. The aim of calculating the fatigue itself is measuring the endurance limit of the structure (14), the marine factor as the factors that can affect the endurance limit on equation (15) also the final endurance limit because during the use because the initial endurance already affected by the marine factor in equation (16). Therefore, the concentration stress occurs because of the hole in the beam. The calculation occurs on the equation (17). Therefore, by taking the value of the normal stress from the principal stress in the dynamic analysis, the assumption of maximum and minimum normal stress can be obtained to find the normal stress reverse. The formula to find the normal stress reverse is shown on equation (20), the value is found to be 58.14 MPa.

From the data, the findings are:

$S y=120 \mathrm{MPa}$ and $\mathrm{Sut}=420 \mathrm{MPa}$

Since Sut $<1400 \mathrm{MPa}$

$$
\begin{aligned}
& S e^{\prime}=0.5 \text { Sut } \ldots \\
& S e^{\prime}=210 \mathrm{MPa}
\end{aligned}
$$

Taking a resource from the Singley book, the parameter of the marine factor with machine finished and the cold draw is known to be:

$$
a=4.51 \text { and } b=-0.265
$$

Then, the marine factor can be calculated using the steps below:

$$
\begin{aligned}
& K a=a x S u t^{b} \\
& K a=0.91 \\
& K b=1 \text { (axial loading) } \\
& K c=0.85 \text { (axial loading) } \\
& K d=\mathrm{Ke}=1
\end{aligned}
$$

The endurance limit will be:

$$
\begin{aligned}
& S e=K a K b K c K d K e S e^{\prime} . \\
& S e=162.435 \mathrm{MPa}
\end{aligned}
$$

Using the appendix on the Shigley book. [8] Specifically in figure A-15-11 that shows a road shaft generated in bending with a transverse hole. Therefore, the FBD will show in figure (8) below.

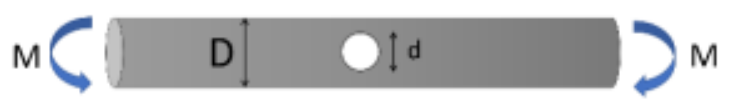

Gambar 8 The stress concentration on frame

$$
\begin{aligned}
& D=2.54 \mathrm{~cm} ; \mathrm{d}=1 \mathrm{~cm} \mathrm{Ka}=0.91 \\
& \frac{d}{D}=0.39
\end{aligned}
$$

From figure $3-\mathrm{Kt}=1.9$

43 Ginanti, D, dkk.; Structure Design And Strength Analysis Of Child Seat For Motorcycle 


$$
\begin{aligned}
& \sqrt{a}=0.246-3.08 \times 10^{-3} \times 60.92+ \\
& 1.52 \times 10^{-5} \times 60.92^{2}-2.67 \times 10^{-8} \times 60.92^{3} \\
& \sqrt{a}=0.108 \sqrt{\text { in }}=0.546 \sqrt{\mathrm{mm}} \\
& K f=1+\frac{(K t-1)}{1+\sqrt{\frac{a}{r}}} \\
& K f=1+\frac{(1.9-1)}{1+\sqrt{\frac{a}{r}}}=1.61
\end{aligned}
$$

From the dynamic calculation, the value of the fluctuating stresses is found to be:

$$
\begin{aligned}
& \sigma_{1}=70.765 \mathrm{MPa} \\
& \sigma_{2}=-0.36 \mathrm{MPa}
\end{aligned}
$$

To avoid the negative stress from the analysis of the dynamics, a new assumption is made to calculate the sigma $\mathrm{m}$ and sigma $\mathrm{a}$.

$$
\begin{aligned}
& \sigma_{\max }=71 \mathrm{MPa} \\
& \sigma_{m n}=10 \mathrm{MPa} \\
& \sigma_{m}=K f x \frac{\sigma_{\max }+\sigma_{\min }}{2} \\
& \sigma_{m}=\frac{71+10}{2}=40.5 \times 1.61=65.21 \mathrm{MPa} \\
& \sigma_{a}=K f x \frac{\sigma_{\max }-\sigma_{\min }}{2} \\
& \sigma_{a}=\frac{71-10}{2}=30.5 \times 1.61=49.11 \mathrm{MPa} \\
& \sigma_{\text {rev }}=\frac{\sigma_{a}}{1-\frac{\sigma_{m}}{\text { Sut }}}=\frac{49.11}{1-\frac{65.21}{420}}=58.14 \mathrm{MPa} \ldots . .
\end{aligned}
$$

After having the value of the normal stress reverse using equation (20), then the next analysis is to compare it with the yield strength of the structure $(\mathrm{Sy}=120 \mathrm{MPa})$. From this comparison, the information on whether the structure will be yielding or not will be known. In this case, since the value of the normal stress reverse is smaller than the yield strength and endurance limit, then, yielding will not occur and the structure will have infinite life.

$$
n f=\frac{1}{\frac{\sigma a}{S e}-\frac{\sigma_{m}}{\text { Sut }}}=\frac{1}{0.15}=6.18
$$

The last analysis is the fatigue safety factor and lifespan. Using the Modified Good-man formula, the safety factor of the structure and the lifespan can be found. Ultimately, it shows that the structure will have an infinite life and the safety factor is 6.8. From all the analysis calculations that already conducted, it can be concluded that the highest safety factor is in the buckling analysis. It is important to give more attention to the safety factor of the legs because of its height since it not only ordinary legs. It includes the damping spring that will minimize the vibration. This is one of the originalities of the product, which makes the baby feel comfortable and minimize the vibration during the motion on the motorcycle.

\section{KESIMPULAN}

The structural design of a child seat for a motorcycle is presented in this paper with some specific specifications following the consumers' needs. What makes this design different from the other product is the base of the legs that are designed to be connected with a certain shape. This shape will allow the seat to stay in its position to avoid falling. The seat is also equipped with a spring-damper system just like what is installed in a bicycle. This spring damper will reduce the effect of vibration due to the motorcycle is ridden on a rough road.[9] In this research, the deal is that a safe child seat for a motorcycle is highly needed. From the analysis that is done in this paper, it comes up with some safety factor values in range 1 until 11 . The lowest value is 1.687 from the analysis of the dynamics and the highest is 11.56 from the buckling analysis. The two other safety factors are 2.15 from the static analysis and 6.8 from the fatigue analysis.

By seeing to these data, the conclusion that is highlighted is that the designed child seat is strength enough to hold a child in a range of 1-5 years old. From the fatigue analysis, the finding also says that the structure is having an infinite life which means that it will not end in a certain cycle. Moreover, no yielding will occur in the structure. This finding shows the strength of the seat and how safe the seat is.

Therefore, from this analysis, some improvement and optimization are possible to be done. Some changing on the dimension or changing to the material may improve the safety factor of the child seat and the seat may become safer. However, for the overall design, this child seat has met its specification and the needs of the consumer. Hence why this innovation is recommended to be applied in the future. A big production for selling this child seat is possible to happen.

\section{DAFTAR PUSTAKA}

[1] Baddoo NR. Stainless steel in construction: A review of research, applications, challenges, and opportunities. Journal of Constructional Steel Research. 2008 Nov 1;64(11):1199-206.

\section{Ginanti, D, dkk.; Structure Design And Strength Analysis Of Child Seat For Motorcycle}


[2] Fukai Z, inventor; Oki Electric Industry Co Ltd, assignee. Shock-absorbing device and chair. The United States patent application US 12/461,669. 2010 Apr 22.

[3] Bitsch HU, inventor; Bitsch Hans Ulrich, assignee. Seating piece of furniture. United States patent US 4,518,202. 1985 May 21.

[4] Cameron RW, inventor; Cameron Robert W, assignee. Vehicle seatbelt having an integral airbag. United States patent US 5,062,662. 1991 Nov 5.

[5] Agran P, Winn D, Dunkle D. Injuries Among 4to 9-Year-Old Restrained Motor Vehicle Occupants by Seat Location and Crash Impact Site. Am J Dis Child. 1989;143(11):1317-1321.

[6] Jain S, Saboo S, Pruncu CI, Unune DR. Performance Investigation of Integrated Model of Quarter Car Semi-Active Seat Suspension with Human Model. Applied Sciences. 2020; 10(9):3185.

[7] Nguyen, SD, Nguyen, QH, Choi, S-B. A hybrid clustering based fuzzy structure for vibration control - part 2: an application to semi-active vehicle seat-suspension system. Mech Syst Signal Process 2015; 56: 288-301.

[8] R. G. Budynas, J. K. Nisbett, and J. E. Shigley, Shigley mechanical engineering design. New York, NY: McGraw-Hill Education, 2020.

[9] Sochacki W, Bold M. Damped vibrations of hydraulic cylinder with a spring-damper system in supports. Procedia Engineering. 2017 Jan 1;177:41-8.

[10]Aoki T, Yamashita Y, Tsubakino D. Vibration Suppression of Mass-Spring-Damper System with Dynamic Dampers using IDA-PBC. IFAC Proceedings Volumes. 2012 Jan 1;45(19):42-7.

45 Ginanti, D, dkk.; Structure Design And Strength Analysis Of Child Seat For Motorcycle 